\title{
Effects of butanol-gasoline blends on SI engine performance, fuel consumption, and emission characteristics at partial engine speeds
}

\author{
Tan Tien Huynh ${ }^{1} \cdot$ Minh Duc Le ${ }^{1} \cdot$ Dinh Nghia Duong ${ }^{1}$
}

Received: 19 January 2019 / Accepted: 17 June 2019 / Published online: 1 July 2019

(C) The Author(s) 2019

\begin{abstract}
The effects of using butanol-gasoline-blended fuels on performance, fuel consumption, and emission characteristics of a four-cylinder spark-ignition engine were experimentally investigated. The butanol-blending fraction was varied from 10 to $50 \%$ by volume. The engine speeds were tested at 2250 and $4250 \mathrm{rpm}$, while the throttle positions were set at $30 \%$ and $70 \%$. The engine performance, specific fuel consumption, and emission properties have been carried out and compared. The results show that, at high throttle position, the flame propagation speed of combustion process as using the butanol-gasoline blends decreases as increasing the butanol-blending fraction and this becomes more obvious with the increase of engine speed. The engine brake torque and power are improved, as the butanol-blending fraction is less than $30 \%$ at low open throttle position, while those are gradually decayed as increasing throttle opening level. A significant reduction is observed in specific fuel consumption, as the butanol-blending fraction is less than $30 \%$ for all the tests. The emissions of $\mathrm{CO}, \mathrm{HC}$, and $\mathrm{CO}_{2}$ in the case of using butanol-gasoline blends are much better than those in the case of using pure gasoline. However, NOx emission is worse than that of the pure gasoline for all the test blends.
\end{abstract}

Keywords Renewable energy $\cdot$ Butanol-gasoline blend $\cdot$ Fuel consumption $\cdot$ Pollutant emissions $\cdot$ Biofuel

$\begin{array}{ll}\text { Abbreviations } \\ \text { AFR } & \text { Air/fuel ratio } \\ \text { RAFR } & \text { Relative air/fuel ratio } \\ \mathrm{Bu} & \text { Percentage of butanol in the fuel (in volume) } \\ \mathrm{BSFC} & \text { Brake-specific fuel consumption } \\ \mathrm{CA} & \text { Crank angle degree } \\ \mathrm{CO} & \text { Carbon monoxide } \\ \mathrm{CO}_{2} & \text { Carbon dioxide } \\ \mathrm{ECU} & \text { Engine control unit } \\ \mathrm{EFI} & \text { Electronic fuel injection } \\ \mathrm{DI} & \text { Direct injection } \\ \mathrm{Me} & \text { Brake torque } \\ \mathrm{Ne} & \text { Engine power } \\ \mathrm{NO} & \text { Nitrogen oxides } \\ \mathrm{PFI} & \text { Port fuel injection } \\ \mathrm{PI} & \text { Port injection } \\ \mathrm{SI} & \text { Spark ignition } \\ n & \text { Engine speed }\end{array}$

Minh Duc Le

minhducle@dut.udn.vn

1 Faculty of Transportation Mechanical Engineering, The University of Danang, University of Science and Technology, 54 Nguyen Luong Bang, Danang, Vietnam

\section{Introduction}

The greenhouse effect is a big concern in our modern world for the last few decades, as it is significantly influenced by the pollutant emissions generated from the combustion of fossil fuels [1]. Consequently, the automotive industry investigators turn their attention to the alcohol as an alternative fuel in an internal combustion engine for the purposes of reducing the carbon-based fossil fuels and protecting the depletion of oil reserves [2-5].

To enhance the combustion efficiency and reduce the emissions, the alcohols (e.g., methanol, ethanol, and butanol) have been investigated and widely used as alternative green fuels in spark-ignition (SI) engines [4, 6-11]. Particularly, methanol can be produced based on many ways, such as coal, natural gas, coke-oven gas, hydrogen, and biomass, while ethanol can be extracted from biomass feedstocks, e.g., corn, sugarcane, barley, and so on [12-14]. It is well known that biomass processing is the most costeffective way to produce the methanol and ethanol $[15,16]$. Using methanol in SI engines could induce lower reactivity of organic emissions when compared to that of pure gasoline and, therefore, reduces the emission products $[17,18]$. However, the methanol combustion induces corrosion on the 
components, which are made of copper, brass, or aluminum [19]. Since producing methanol is mostly required either coal- or petroleum-based fuels, ethanol has been widely used in biofuel and blending agents as a commercial fuel [20-23]. Ethanol can be used in different types of internal combustion engines, even without any modification made for the engine. Besides, ethanol- and methanol-gasoline blends burn in a cleaner manner and release fewer emissions compared to those of pure gasoline $[21,24,25]$. In addition, methanol and ethanol have a greater enthalpy of vaporization, larger octane number, faster flame speed, and less stoichiometric air/fuel ratio compared to those of pure gasoline [26-28].

Compared to methanol and ethanol, butanol has a lower vapor pressure, better blending ability, and greater energy density when used in IC engines [7, 27, 29-31]. Therefore, these prominent characteristics of butanol would help improve the engine performance and pollutant emissions. Many investigators have examined the performance and emissions of IC engines using butanol. For instance, Feng et al. [32] studied the performance and pollutant emissions on an SI engine fueled with the butanol-gasoline blend. The experiment was carried out at full load (for an engine speed ranged from 3500 to $9000 \mathrm{rpm}$ ) and partial loads (at the engine speed of $6500 \mathrm{rpm}$ and $8500 \mathrm{rpm}$ ) for $35 \%$ butanol-blending fraction. An additional of $1 \% \mathrm{H}_{2} \mathrm{O}$ was added into the blends to recover the engine performance and control the NOx emission. The results showed that the engine torque, brake-specific energy consumption, $\mathrm{CO}$, and $\mathrm{HC}$ emissions are better than those of pure gasoline. The effects of the butanol-gasoline blend on engine performance, fuel economy, and emissions are similar to those occurred at the engine full load and partial loads. Singh et al. [33] performed a study on butanol-gasoline blends for a powering-duty transportation SI engine. The experiments were conducted at four different engine speeds of $1500,2500,3500$, and $4500 \mathrm{rpm}$, while the engine torque was controlled less than $66 \mathrm{Nm}$. The engine performance, emissions, and combustion characteristics were revealed using different butanol-blending fraction in the blend, e.g., $5,10,20,50$, and $75 \%$. The authors concluded that the performance, emissions, and combustion characteristics of the engine using butanol-gasoline blends are similar to those as using gasoline. The performance of an SI engine using gasoline and two butanol-blending fractions (i.e., 20\% and $40 \%$ butanol by mass) at low and medium engine speeds and loads were reported by Galloni et al. [34]. Results showed that the engine torque and thermal efficiency are slightly decreased as increasing the butanol-blending fraction. The burning rate of lean mixtures increases with increasing butanol-blending fraction and there is no adjustment needed for spark advance as changing the pure gasolineto-butanol-gasoline blends. Compared to the use of pure gasoline, there is no significant change were made on NOx and $\mathrm{CO}$ emissions as using butanol-gasoline blends, while a slight difference was recorded on $\mathrm{HC}$ and $\mathrm{CO}_{2}$ emissions. Yang et al. [35] claimed that butanol is a promising alternative fuel by performing butanol-gasoline blends (e.g., 30\% and $35 \%$ butanol by volume) without modifying a carburetor SI engine. Results indicated that the energy can be saved by reducing $14 \%$ in brake-specific energy consumption and the emissions are significantly reduced compared to pure gasoline. However, the NOx emission is gradually increased as increasing butanol-blending fraction.

Although there are many types of research concerning $n$-butanol-gasoline blends in SI engines, the relationship between the engine speed, throttle position, and butanolblending fraction, which affect the performance, fuel consumption, and emissions of the engine, has not been completely investigated at the same time. Besides, the information of comparison between different butanol-gasoline blends and pure gasoline is still limited. Therefore, this study presents the experimental results conducted with different throttle positions and engine speeds as well as butanolblending fractions. The engine performance in terms of incylinder pressure, brake torque, power, and brake-specific fuel consumption has been examined and compared for both butanol-gasoline blends and pure gasoline. The blending ratio applied of $n$-butanol-gasoline in fuel mixture is covered for the range of $10-50 \mathrm{vol} . \%$. In addition, the emission characteristics of the engine in term of $\mathrm{CO}, \mathrm{HC}, \mathrm{CO}_{2}$, and NOx have been presented and discussed.

\section{Experimental methods}

\section{Apparatus}

The experiments were conducted at the Internal Combustion Engine Laboratory of The Danang University, University of Science and Technology. Figure 1 shows the schematic diagram of the experimental setup. A 4-cylinder, 16-valve, 1.6-L spark-ignition Daewoo engine, model A16DMS with a compression ratio of 9.5 was used to perform experiments. To examine the effects of using butanol-gasoline blends on the engine performance and emission characteristics, there is no modification made for the test engine. The specifications of the test engine are given in Table 1. An eddy-current dynamometer (model APA 204/08) was used to measure torque and power of the engine. An inline mass flow meter (model DN-80; AVL) was used to measure the air-intake consumption. A leveling and measuring fuel consumption device (model $733 \mathrm{~s}$; AVL) was used to control the fuel consumption and fuel temperature. A throttle actuator (model THA-100; AVL) was used to control the open throttles at different engine speeds. A gas analyzer (model KEG-500) was used to estimate simultaneously the air-fuel equivalence 


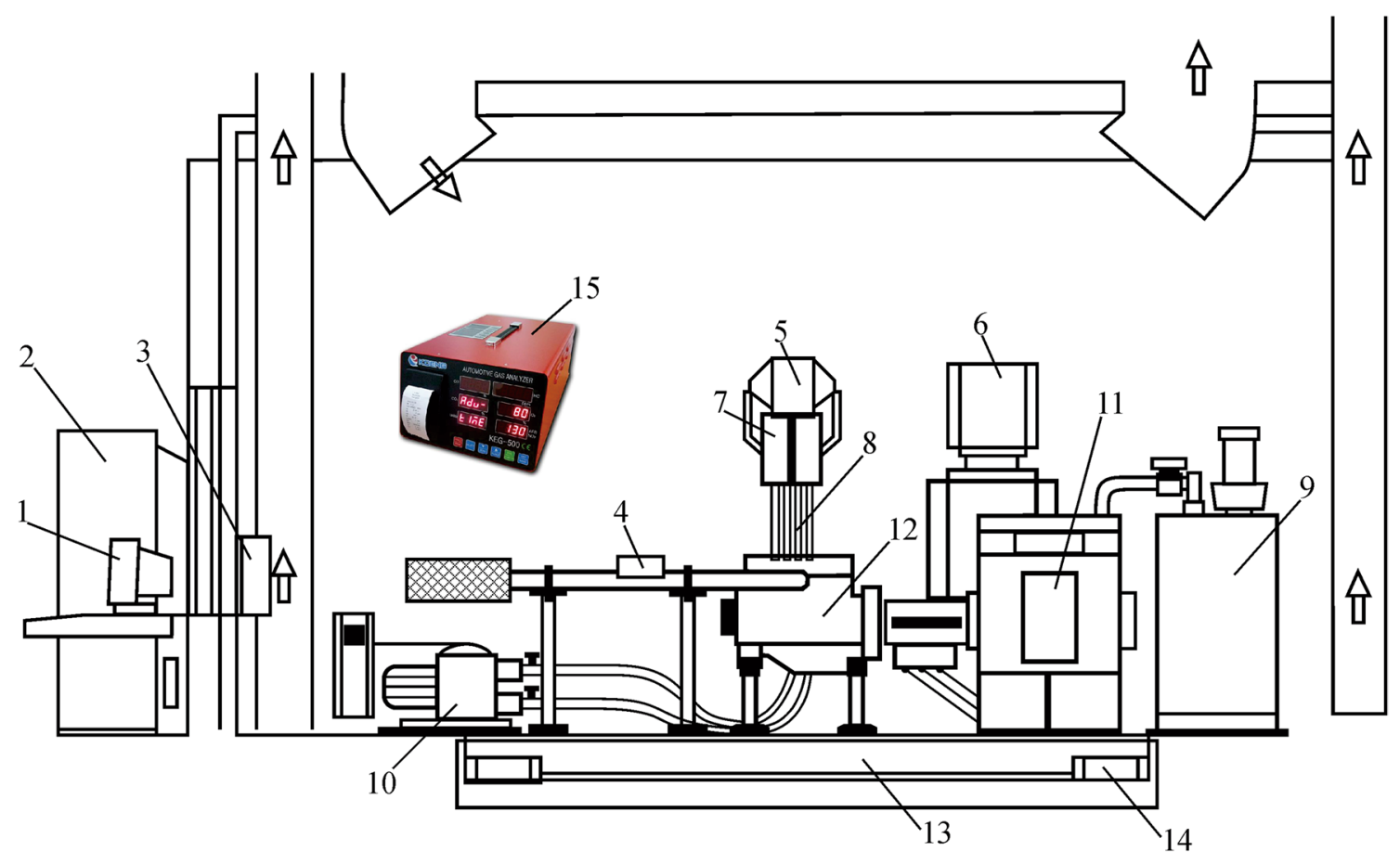

Fig. 1 Experimental setup. 1. Computer center 2. Puma data-processing center 3. Throttle valve-opening controller THA-100 4. Air flow meter 5. Catch gas at caster 6. Leveling and measuring fuel consumption AVL733s 7. Data acquisition 8. Sensors mounted on the engine

Table 1 Specifications of the test engine

\begin{tabular}{ll}
\hline Engine type & DOHC \\
\hline Number of cylinders/arrangement & 4 cylinders/inline \\
Bore $(\mathrm{mm}) \times$ Stroke $(\mathrm{mm})$ & $79.0 \times 81.5$ \\
Compression ratio & $9.5: 1$ \\
Maximum output & $80 \mathrm{~kW}$ at $6000 \mathrm{rpm}$ \\
Maximum torque & $145 \mathrm{Nm}$ at $3400 \mathrm{rpm}$ \\
Fuel system & Electronic fuel injection \\
\hline
\end{tabular}

ratio based on the composition of the exhaust. A pressure transducer (model IndiSet 620; AVL) mounted on the cylinder head near the spark plug was used to detect the incylinder pressure. The AVL 553 and AVL 554 devices were used as cooling system and lubricant system for the test rig, respectively.

\section{Testing strategy}

In this study, an original fuel injection strategy controlled by the ECU was set to control the fuel injection timing and ignition system based on the use of pure gasoline. The stoichiometric air/fuel ratio (AFR) of butanol and gasoline is 11.12 and 14.7, respectively. Therefore, the butanol-gasoline blends are always run at a higher AFR. This configuration
9. Engine's water coolant-conditioning controller 10. Engine's lubricant supplying system AVL554 11. 204/8 APA dynamometer 12. Engine 13. Test base 14. Damper system 15. Gas analyzer KEG-500

could help archive a lean burning for the engine due to limitation of AFR control [36]. The engine torque, power, fuel consumption, and pollutant emissions of an engine using butanol-gasoline-blended fuels were investigated and compared to those of using pure gasoline under the operations without any modification to the engine. The engine was fueled with different butanol-gasoline blends of $\mathrm{Bu} 0$, $\mathrm{Bu} 10, \mathrm{Bu} 15, \mathrm{Bu} 20, \mathrm{Bu} 25, \mathrm{Bu} 30, \mathrm{Bu} 40$, and Bu50, indicating the content of butanol in different volume ratios (e.g., Bu10 contains $10 \%$ butanol and $90 \%$ gasoline in volume). Two different wide open throttles (WOT) positions of $30 \%$ and $70 \%$ were set for the experiments, while the engine speed was tested at $2250 \mathrm{rpm}$ and $4250 \mathrm{rpm}$. The properties of gasoline and butanol are given in Table 2. The operating parameter (e.g., relative air/fuel ratio and in-cylinder pressure), engine performance factors (e.g., brake toque, power, and fuel consumption) and pollutant emissions (e.g., $\mathrm{HC}, \mathrm{CO}, \mathrm{NOx}$, and $\mathrm{CO}_{2}$ ) were measured and compared for the test fuels.

\section{Results and discussion}

\section{In-cylinder pressure}

The relative air/fuel ratio (RAFR) during the tests for different butanol-gasoline blends at opening throttle levels 
Table 2 Properties for Butanol and gasoline fuel [35, 40-43]

\begin{tabular}{lll}
\hline Fuel property & Butanol & Gasoline \\
\hline Formula & $\mathrm{C}_{4} \mathrm{H}_{9} \mathrm{OH}$ & $\mathrm{C}_{8} \mathrm{H}_{15}$ \\
Octane number & 96 & $90-99$ \\
Composition $(\mathrm{C}, \mathrm{H}, \mathrm{O})(\%$ mass $)$ & $65,13.5,21.5$ & $86,14,0$ \\
Density $\left(\mathrm{kg} / \mathrm{m}^{3}\right)$ at $20^{\circ} \mathrm{C}$ & 810 & 745 \\
Boiling point $\left({ }^{\circ} \mathrm{C}\right)$ & 117.7 & $25-215$ \\
Latent heat of vaporization $(\mathrm{kJ} / \mathrm{kg})$ at $25{ }^{\circ} \mathrm{C}$ & 582 & 223.2 \\
Saturation pressure $(\mathrm{kPa})$ at $38^{\circ} \mathrm{C}$ & 2.27 & 31.01 \\
Low heating value $(\mathrm{MJ} / \mathrm{kg})$ & 33.3 & 43 \\
Auto ignition temperature $\left({ }^{\circ} \mathrm{C}\right)$ & 385 & 420 \\
Stoichiometric air/fuel ratio & 11.12 & 14.7 \\
\hline
\end{tabular}

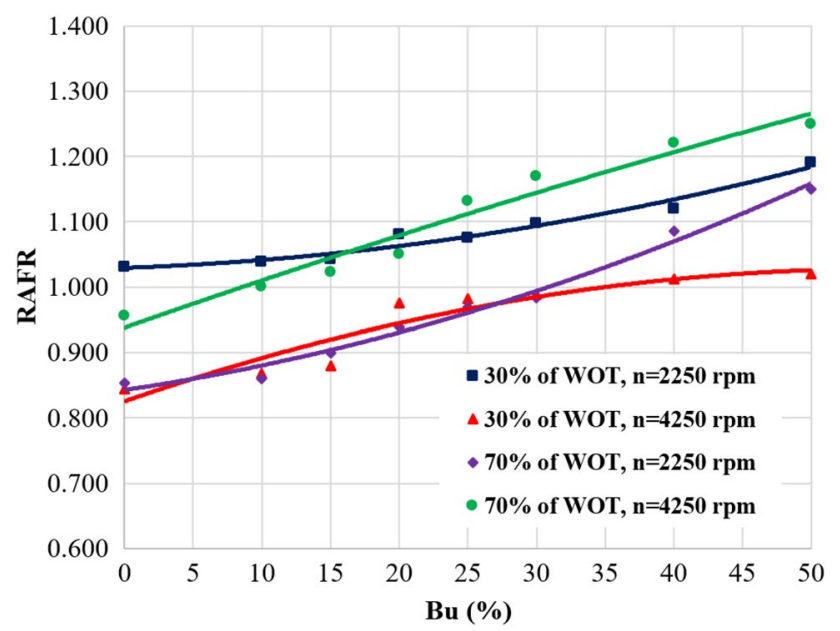

Fig. 2 Relative air-fuel ratio during the test with different butanolgasoline-blended fuels

of 30\% and 70\% is shown in Fig. 2. As shown in Fig. 2, the RAFR increases as increasing the butanol-gasoline blends compared to that of pure gasoline for both cases of low and high throttle opens. For low throttle position (i.e., 30\% of WOT), at any fixed butanol-blending fraction, the RAFR decreases as increasing the engine speed. For instance, the RAFR at $n=2250 \mathrm{rpm}$ is reduced about 16,10 , and $14 \%$ as the butanol blend ratio of 10,30 , and $50 \%$, respectively, compared to that at $n=4250 \mathrm{rpm}$. In contrast, at high throttle position (i.e., 70\% of WOT), for any fixed butanol-blending fraction, the RAFR increases with increasing the engine speed. For instance, the increment of RAFR at $n=4250 \mathrm{rpm}$ is about 16,19 , and $9 \%$ for Bu10, Bu30, and Bu50, respectively, compared to that at $n=2250 \mathrm{rpm}$. In other words, the RAFR in the case of using butanol-gasoline blends at either low or high throttle position exhibit a higher value than that in the case of using pure gasoline; therefore, the fuel mixture is leaner.
The temporal variation of in-cylinder pressure for various butanol-gasoline blends at the opening throttle levels of $30 \%$ and $70 \%$ and engine speed of 2250 and $4250 \mathrm{rpm}$ is shown in Fig. 3. For clarity presentation, four butanol-gasoline blends are selected to compare as $\mathrm{Bu} 0, \mathrm{Bu} 10, \mathrm{Bu} 30$, and Bu50. To compare the combustion characteristics of blended fuels to pure gasoline (i.e., Bu0), the in-cylinder pressure is considered to be one of the most important parameters. In the case of using pure gasoline, it is observed that the incylinder pressure increases as increasing the open throttle level. As illustrated in Figs. 3a-d, at a fixed open throttle, the maximum in-cylinder pressure increases with increasing the engine speed. As shown in Fig. 3a (30\% of WOT, $n=2250 \mathrm{rpm}$ ), the maximum in-cylinder pressure exhibits a slight increment of 5\%, as the butanol-blending fraction is low (e.g., Bu10) compared to the pure gasoline (i.e., Bu0). However, as the butanol blend ratio increases, the maximum in-cylinder pressure is decreased gradually. For instance, the peak value of in-cylinder pressure is reduced by $12 \%$ and $19 \%$ as using Bu30 and Bu50, respectively, compared to that of using pure gasoline (i.e., Bu0). As the engine speed increases, in Fig. $3 \mathrm{~b}(n=4250 \mathrm{rpm})$, the increasing rate of in-cylinder pressure when using $\mathrm{Bu} 10$ and $\mathrm{Bu} 30$ is about $8 \%$ and $6 \%$, respectively, compared to pure gasoline. It is also shown that when the addition of butanol goes beyond $30 \%$ in the blend (e.g., Bu50), the peak value of in-cylinder pressure starts to decrease consequently. For instance, the reduction of maximum in-cylinder pressure for the case of $\mathrm{Bu} 50$ is about $6 \%$ compared to that of $\mathrm{Bu} 0$ case.

At a high throttle position (i.e., 70\% of WOT) and an engine speed of $n=2250 \mathrm{rpm}$ (Fig. 3c), the peak value of in-cylinder pressure in the case of Bu0 exhibits a larger value compared to that of the other butanol-gasoline blends. The peak value of in-cylinder pressure is decreased gradually, as increasing the butanol-blending fraction. For instance, the reduction of maximum in-cylinder pressure for the case of $\mathrm{Bu} 10, \mathrm{Bu} 30$, and $\mathrm{Bu} 50$ is about $11.5,13$, and $17 \%$, respectively, compared to that of $\mathrm{Bu} 0$ case. This is because the butanol-gasoline blends have a lower heating value compared to that of pure gasoline (Table 2).

Similar to that occurred in Fig. 3c, at the engine speed of $n=4250 \mathrm{rpm}$ (as shown in Fig. 3d), the peak value of incylinder pressure drops as increasing the butanol-blending fraction due to the low heating value of the blends and nonhomogeneous of the fuel mixture. This is because lean air/ fuel mixtures (Fig. 2) burn more slowly than stoichiometric mixtures leading to lower peak pressures appearance. In this study, the formation of in-cylinder pressure can be used to explain the behavior of laminar flame speed (or flame propagation speed) when using different blends, since the sparkignition timing is fixed. As shown in Fig. 3c, d, the flame propagation speed of the blend fuels decreases as increasing the butanol-blending fraction. This happens more obvious 
Fig. 3 In-cylinder pressure of engine using different butanolgasoline-blended fuels
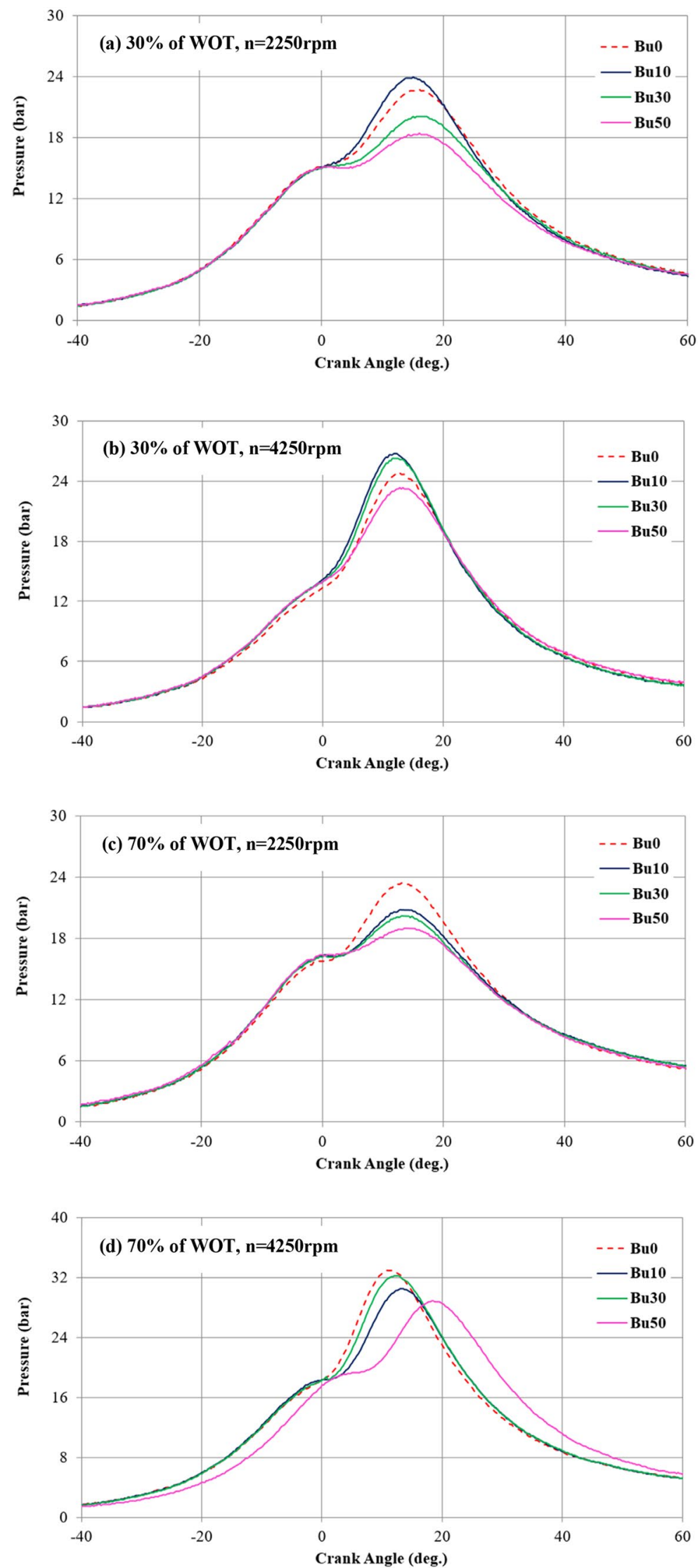


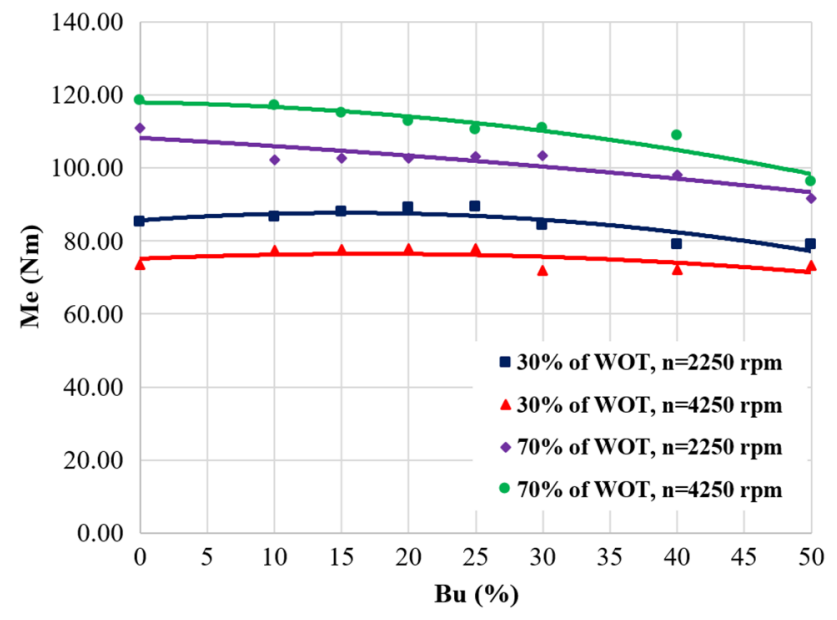

Fig. 4 Brake torque of engine using different butanol-gasolineblended fuels

as increasing the engine speed due to the greater latent heat of vaporization in the blends.

\section{Brake torque and power}

The output brake toque (Me) of the engine using different butanol-gasoline blends at the opening throttle levels of $30 \%$ and $70 \%$ and engine speeds of $n=2250$ and $4250 \mathrm{rpm}$ is shown in Fig. 4.

As shown in Fig. 4, the brake torque values increase rapidly as increasing the throttle valve opening for all the test cases. For instance, at the butanol-blending fraction of $20 \%$, the brake torque is about 89 and $103 \mathrm{Nm}$ as $30 \%$ and $70 \%$ of WOT, respectively, at the engine speed of $n=2250 \mathrm{rpm}$, while it is about 78 and $113 \mathrm{Nm}$ as an open throttle of $30 \%$ and $70 \%$, respectively, at the engine speed of $n=4250 \mathrm{rpm}$. In general, at low throttle position (i.e., 30\% of WOT), the brake torque is slightly increased with increasing the percentage of butanol in butanol-gasoline blended and reaches a peak at $\mathrm{Bu} 25$. For instance, the increment of brake torque at $\mathrm{Bu} 25$ is about $5 \%$ and $6 \%$ compared to pure gasoline at $n=2250$ and $4250 \mathrm{rpm}$, respectively. When the butanolblending fraction goes beyond $30 \%$, the brake torque starts to decrease slightly, as the RAFR increases rapidly (Fig. 2). At high throttle position (i.e., 70\% of WOT), the brake torque decreases gradually as increasing the butanol-gasoline blend ratio. This is because the pure gasoline exhibits a low value of the latent heat and a high value of the saturation vapor pressure as compared to those of butanol [37-41]. For instance, as shown in Table 2, the low heating value and saturation vapor pressure of the pure gasoline are 43 and 31.01, respectively, while those of butanol are 33.3 and 2.27 , respectively. Therefore, the evaporation time of pure gasoline after injecting is shorter when compared to that of

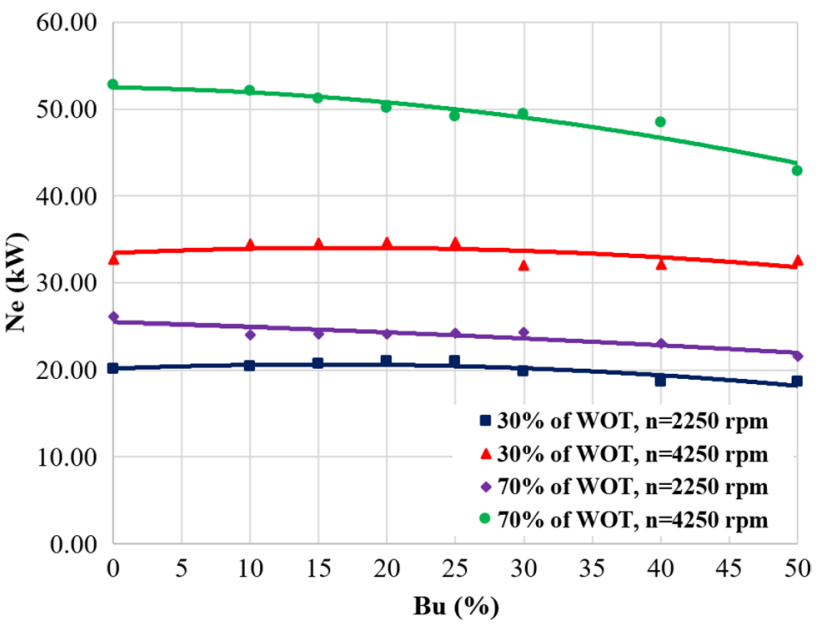

Fig. 5 Power of engine using different butanol-gasoline-blended fuels

butanol-gasoline blends. A higher percentage of butanol in blends causes a non-homogeneous mixture and might lead to an incomplete combustion; therefore, the brake torque is reduced appropriately.

Figure 5 presents the power of engine for the different blends studied. As illustrated in Fig. 5, the power of engine exhibits a scenario similar to that presented in brake torque for all the tests (Fig. 4). The power of engine increases significantly as increasing the throttle opening due to the increment of air-intake efficiency for all the test cases of butanol-gasoline blends. For example, at $30 \%$ of WOT, for the case of Bu25, the power of the engine is about 21 and $35 \mathrm{~kW}$ for the engine speed of $n=2250 \mathrm{rpm}$ and $4250 \mathrm{rpm}$, respectively. Similarity, at $70 \%$ of WOT, the engine power is approximately 24 and $49 \mathrm{~kW}$ for the engine speed of $n=2250$ and $4250 \mathrm{rpm}$, respectively, at the butanol-blending fraction of $25 \%$. It is also observed that, at a low throttle position (i.e., $30 \%$ of WOT), a slight increment of engine power occurred; since the butanol-blending fraction is less than $30 \%$, then it is decreased slightly as butanol-gasoline ratio goes beyond $30 \%$. This is because of the distribution of fuel vapor in the combustion chamber that the moment of ignition at low opening throttle-level condition might be better than that of the higher one. Therefore, the performance is improved appropriately. Besides that, at a high throttle position (e.g., 70\% of WOT), the power of the engine is decreased as increasing the butanol-blending fraction due to the higher heat of evaporation of butanol-gasoline blends compared to that of pure gasoline (Table 2).

\section{Specific fuel consumption}

The brake-specific fuel consumption (BSFC) of the engine using different butanol-gasoline blends at various opening 


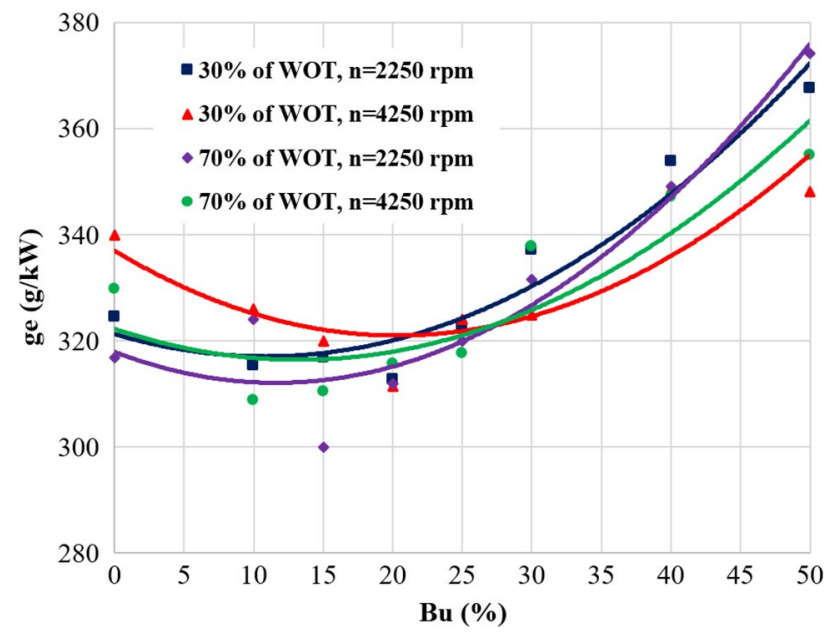

Fig. 6 Specific fuel consumptions for different butanol-gasolineblended fuels

throttle levels and engine speeds is shown in Fig. 6. The BSFC $(\mathrm{g} / \mathrm{kWh})$ is defined as the ratio of the rate of fuel consumption $(\mathrm{g} / \mathrm{h})$ and the brake power $(\mathrm{kW})$. As shown in Fig. 6, the BSFC in the cases of using butanol-gasoline blend exhibits a significant reduction compared to that in the case of using pure gasoline, since the blends ratio is less than $30 \%$, which results from the decrease of brake torque and power (as shown in Figs. 4 and 5). For instance, at 30\% of WOT and Bu20, the reduction on BSFC is about $3.6 \%$ and $8.4 \%$ for the engine speeds of $n=2250$ and $4250 \mathrm{rpm}$, respectively. At $70 \%$ of WOT and $\mathrm{Bu} 20$, the BSFC is reduced by $1.5 \%$ and $4.3 \%$ for the engine speeds of $n=2250$ and $4250 \mathrm{rpm}$, respectively. However, as the butanol concentration in the blend is greater than $30 \%$, the BSFC starts to increase rapidly. It means that for the same operating conditions, the engine needs to burn more butanol-gasoline blend than pure gasoline. This is because of the disadvantages of butanol, which are the lower air-to-fuel ratio for stoichiometric mixtures and lower heating value when compared to those of pure gasoline (Table 2).

\section{Emission characteristics}

The carbon monoxide ( $\mathrm{CO}$ ) is one of the toxic gas need to be reduced and controlled for the SI engine. The $\mathrm{CO}$ could induce incomplete combustion and poor air-fuel management [36]. The existence of oxygen in fuel exhibits a major effect on $\mathrm{CO}$ emission in the SI engine [42]. Figure 7 presents $\mathrm{CO}$ emissions of butanol-gasoline blends and pure gasoline at different throttle positions of $30 \%$ and $70 \%$ and engine speeds of $n=2250$ and $4250 \mathrm{rpm}$. It is observed that $\mathrm{CO}$ emissions of using butanol-gasoline blends at various opening throttle levels are much lower than that of using pure gasoline. In addition, the $\mathrm{CO}$

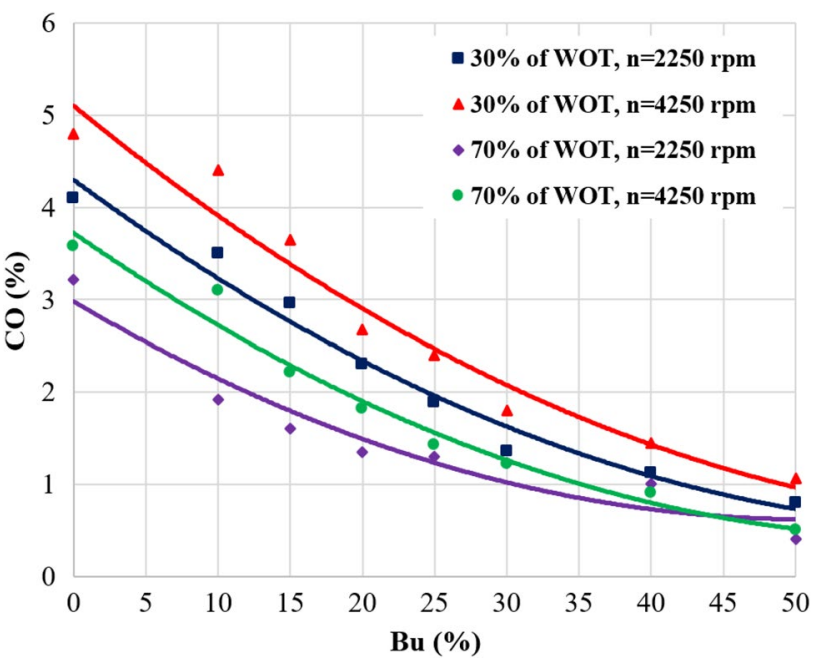

Fig. 7 Carbon-monoxide emissions for different butanol-gasolineblended fuels

emission decreases gradually with increasing butanol concentration in blends. This is because the butanol-gasoline blend fuel burns more thoroughly than pure gasoline due to its higher RAFR (Fig. 2) and lower carbon content. At higher RAFR, i.e., higher oxygen in the air, the $\mathrm{CO}$ emissions are lower than that at lower RAFR. In addition, a higher percentage of butanol in blends leads lower carbon content compared to that in pure gasoline, so that the $\mathrm{CO}$ emissions (as using butanol-gasoline blends) are lower than those exhibited in pure gasoline case. This observation is well agreed with several studies before [36, 37, 43]. In other words, the $\mathrm{CO}$ emission is significantly influenced by the properties of fuel (i.e., butanol-gasoline blends).

Figure 8 shows the hydrocarbon (HC) emissions of butanol-gasoline blends and pure gasoline at different throttle positions and engine speeds. It is well known that the $\mathrm{HC}$ emissions mainly result from engine misfiring and poor/incomplete combustion. Besides that, the amount of unburned $\mathrm{HC}$ depends on the engine operating conditions and fuel properties [36, 42]. As illustrated in Fig. 8, at $30 \%$ of WOT, the higher butanol blend ratio, the lower the $\mathrm{HC}$ emission for a butanol concentration in blend less than $30 \%$. However, when the butanol concentration goes beyond $30 \%$, due to the burning of small fuel quantity, a lower temperature occurs during combustion; therefore, it induces poor vaporization and mixing of fuel and air. Consequently, incomplete combustion of inhomogeneous charge leads to increment of $\mathrm{HC}$ emissions. At $70 \%$ of WOT and engine speed of $n=2250 \mathrm{rpm}$, the trend of HC emission displays the same as that of $\mathrm{CO}$ emission, since the butanol-gasoline blend fuel contents lower carbon and better combustion process than pure gasoline. It is also shown that, at an engine speed of $n=4250 \mathrm{rpm}$, the HC 


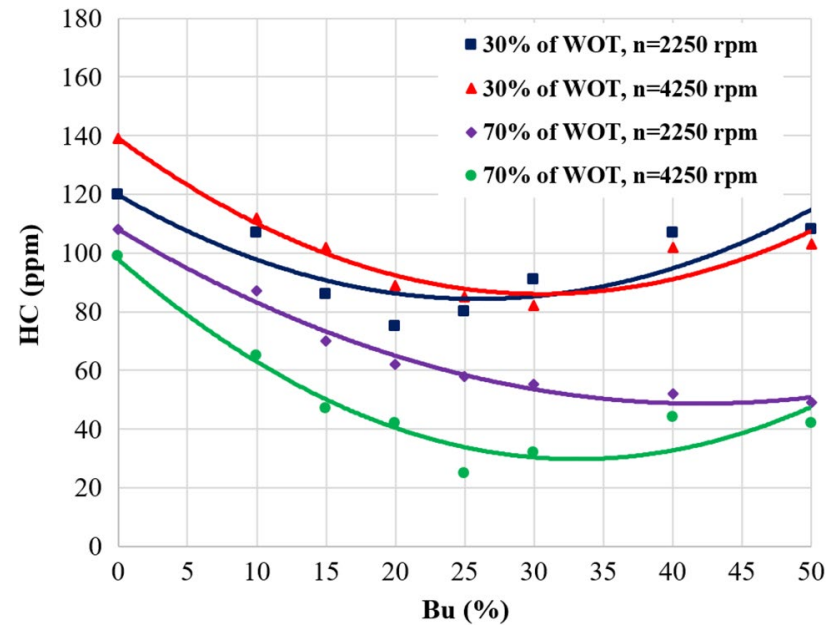

Fig. 8 Unburned hydrocarbon emissions for different butanol-gasoline-blended fuels

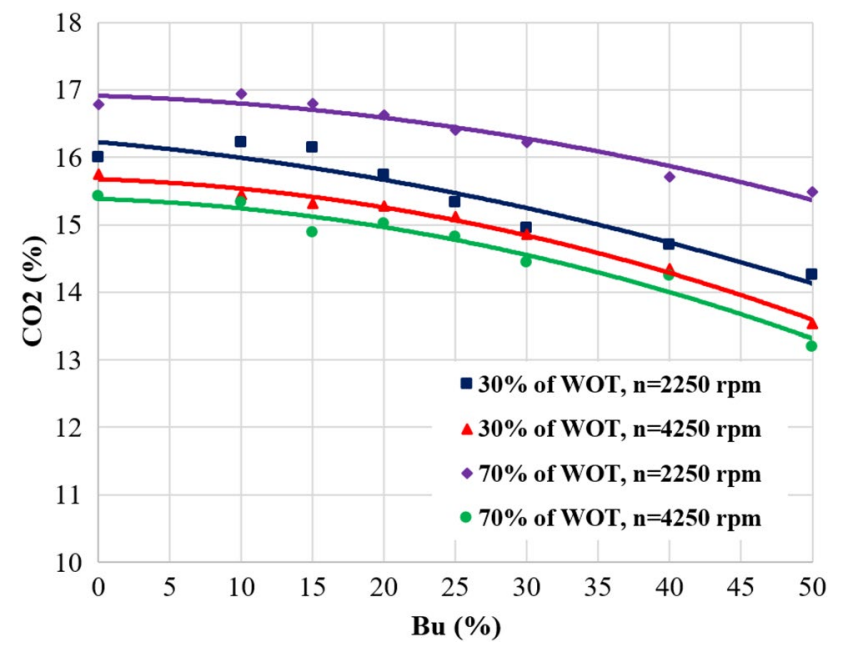

Fig. 9 Carbon dioxide emissions for different butanol-gasolineblended fuels

emission at high throttle position exhibits a similar scenario like that at a lower one.

Figure 9 presents the carbon dioxide $\left(\mathrm{CO}_{2}\right)$ emissions for all the test fuels at different opening throttle levels and engine speeds. The observation on results shows that low engine speed (i.e., $n=2250 \mathrm{rpm}$ ) provides higher $\mathrm{CO}_{2}$ emissions compared to that of high engine speed (i.e., $n=4250 \mathrm{rpm}$ ) due to the increase of oxygen content and extra lean mixture. As shown in Fig. 9, it is worth noting that the $\mathrm{CO}_{2}$ emission exhibits a reduction with increasing the butanol-gasoline blend ratio due to the lean mixture condition (Fig. 2). For instance, at the engine speed of $n=4250 \mathrm{rpm}$, the $\mathrm{CO}_{2}$ emissions with the use of $\mathrm{Bu} 40$ at $30 \%$ and $70 \%$ of WOT are decreased by $9 \%$ and $8 \%$, respectively, compared with that of pure gasoline. This reduction

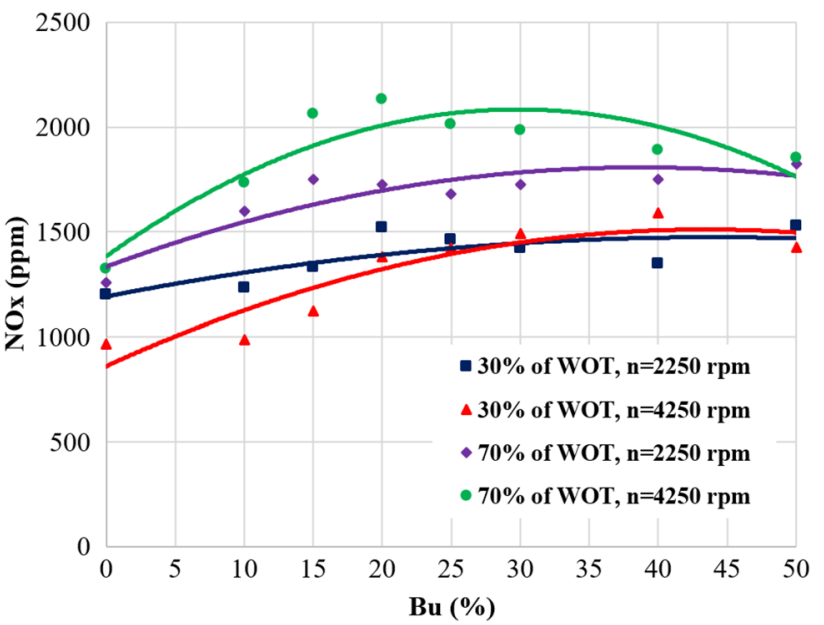

Fig. 10 Nitrogen oxide emissions for different butanol-gasolineblended fuels

links unlike carbon contents in the butanol and gasoline fuels (Table 2). It is also found that $\mathrm{CO}_{2}$ emission in the case of high throttle position (i.e., 70\% of WOT) and engine speed of $n=4250 \mathrm{rpm}$ is lower than that in the case of low throttle position (30\% of WOT) for any butanol-gasoline blend ratio. This can be explained that the engine operated at low opening throttle level using butanol-gasoline blends can provide higher efficiency of combustion process than that at high throttle position.

The formation of nitrogen oxides (NOx) as using butanol-gasoline blends and pure gasoline is revealed in Fig. 10. It is well known that the NOx is depended on many factors, such as engine load, temperature, combustion chamber content, and mixture density [36, 42]. As shown in Fig. 10, NOx emission in the case of using butanol-gasoline blends is significantly higher than that in the pure gasoline case at all the test blends and engine speeds. It is also shown that the NOx emission in the case of WOT 70\% is greater than that in the case of WOT $30 \%$. Particularly, at a fixed opening throttle level, the increment of NOx emission at low engine speed is significantly lower than that at a high engine speed as the butanol-blending fraction less than 30\%. For instance, for WOT 30\% and $\mathrm{Bu} 25$, the increment of NOx emission is about $22 \%$ and $47 \%$ compared to that of pure gasoline (i.e., $\mathrm{Bu} 0$ ) at the engine speeds of $n=2250$ and $4250 \mathrm{rpm}$, respectively. While, for WOT $70 \%$ and Bu25, this value is about $33 \%$ and $52 \%$ at the engine speeds of $n=2250$ and $4250 \mathrm{rpm}$, respectively. The observation on NOx emission is induced by (1) the effects of advancing the spark timing, this might bring the combustion gas temperature in the case of butanol-gasoline blends is higher than that in the case of pure gasoline [35] and (2) the butanol-gasoline blend contains oxygen and a low stoichiometric AFR (Table 2). 
The testing strategy for the engine was set for pure gasoline and it is not possible to adjust the AFR, as mentioned in Sect. 2.2. In other words, the AFR was kept at the same value for a given condition; therefore, the combustion was relatively leaner and more oxygen to produce NOx. Consequently, the NOx emission is increased appropriately as increasing the concentration of butanol in the blends. Further research is, therefore, required to reduce the NOx emissions.

\section{Conclusions}

The effects of using different butanol-gasoline blends on performance, fuel consumption, and emissions of a fourcylinder SI engine operated at low and high throttle positions as well as low and high engine speeds have been experimentally studied. The main findings are highlighted as follows:

1. Without any modification made for the engine, at high throttle position, the flame speed of the butanol-gasoline blends decreases as increasing the butanol-blending fraction. This becomes more obvious with the increase of the engine speed.

2. The engine brake torque and engine power are increased, and the specific fuel consumption is decreased when compared to those of pure gasoline under the condition of low throttle position since the butanol fraction less than $30 \%$. At $30 \%$ of WOT, when the butanol-blending fraction goes beyond $30 \%$, the brake torque decreases slightly as the RAFR increases rapidly. At 70\% of WOT, the brake torque decreases gradually as increasing the butanol-gasoline blend ratio.

3. As the concentration of butanol in blend increases, for both cases of $30 \%$ and $70 \%$ of WOT, using butanol-gasoline blends produce significant reductions on $\mathrm{CO}, \mathrm{HC}$, and $\mathrm{CO}_{2}$ emissions compared to those of pure gasoline.

4. NOx emission is increased as increase the butanolblending fraction and it is significantly higher than that of the pure gasoline. For the same condition of engine speed, the higher the throttle position, the greater the NOx emissions.

Acknowledgements This work was funded by The University of Danang-University of Science and Technology under project number T2018-02-05.

\section{Compliance with ethical standards}

Conflict of interest The authors declare that they have no conflict of interest.
Open Access This article is distributed under the terms of the Creative Commons Attribution 4.0 International License (http://creativeco mmons.org/licenses/by/4.0/), which permits unrestricted use, distribution, and reproduction in any medium, provided you give appropriate credit to the original author(s) and the source, provide a link to the Creative Commons license, and indicate if changes were made.

\section{References}

1. Nel, W.P., Cooper, C.J.: Implications of fossil fuel constraints on economic growth and global warming. Energy Policy 37(1), $166-180$ (2009)

2. Wallner, T., and Frazee, R. Study of regulated and non-regulated emissions from combustion of gasoline, alcohol fuels and their blends in a DI-SI engine. SAE technical paper, 2010

3. Fleming, D., Chamberlin, S.: Teqs (Tradable Energy Quotas): A Policy Framework for Peak Oil and Climate Change. All-Party Parliamentary Group on Peak Oil, and The Lean Economy Connection, London (2011)

4. Surisetty, V.R., Dalai, A.K., Kozinski, J.: Alcohols as alternative fuels: an overview. Appl. Catal. A 404(1-2), 1-11 (2011)

5. Kumar, S., Cho, J.H., Park, J., Moon, I.: Advances in dieselalcohol blends and their effects on the performance and emissions of diesel engines. Renew. Sustain. Energy Rev. 22, 46-72 (2013)

6. Agarwal, A.K.: Biofuels (alcohols and biodiesel) applications as fuels for internal combustion engines. Prog. Energy Combust. Sci. 33(3), 233-271 (2007)

7. Elfasakhany, A.: Experimental study on emissions and performance of an internal combustion engine fueled with gasoline and gasoline/n-butanol blends. Energy Convers. Manage. 88, 277-283 (2014)

8. Liu, S., Clemente, E.R.C., Hu, T., Wei, Y.: Study of spark ignition engine fueled with methanol/gasoline fuel blends. Appl. Therm. Eng. 27(11-12), 1904-1910 (2007)

9. Venugopal, T., Ramesh, A.: Effective utilisation of butanol along with gasoline in a spark ignition engine through a dual injection system. Appl. Therm. Eng. 59(1-2), 550-558 (2013)

10. Zhen, X., Wang, Y.: An overview of methanol as an internal combustion engine fuel. Renew. Sustain. Energy Rev. 52, 477493 (2015)

11. Elfasakhany, A.: Investigations on performance and pollutant emissions of spark-ignition engines fueled with $n$-butanol-, isobutanol-, ethanol-, methanol-, and acetone-gasoline blends: a comparative study. Renew. Sustain. Energy Rev. 71, 404-413 (2017)

12. Li, Y., Gong, J., Deng, Y., Yuan, W., Fu, J., Zhang, B.: Experimental comparative study on combustion, performance and emissions characteristics of methanol, ethanol and butanol in a spark ignition engine. Appl. Therm. Eng. 115, 53-63 (2017)

13. Costa, R.C., Sodré, J.R.: Compression ratio effects on an ethanol/gasoline fuelled engine performance. Appl. Therm. Eng. 31(2-3), 278-283 (2011)

14. Celik, M.B.: Experimental determination of suitable ethanol-gasoline blend rate at high compression ratio for gasoline engine. Appl. Therm. Eng. 28(5-6), 396-404 (2008)

15. Shamsul, N.S., Kamarudin, S.K., Rahman, N.A., Kofli, N.T.: An overview on the production of bio-methanol as potential renewable energy. Renew. Sustain. Energy Rev. 33, 578-588 (2014)

16. Leduc, S., Lundgren, J., Franklin, O., Dotzauer, E.: Location of a biomass based methanol production plant: a dynamic problem in northern Sweden. Appl. Energy 87(1), 68-75 (2010)

17. Akutsu, Y., Toyoda, F., Tomita, K.I., Yoshizawa, F., Tamura, M., Yoshida, T.: Effect of exhaust from alcohol fuel on ozone 
formation in the atmosphere. Atmos. Environ. Part A Gen. Top. 25(7), 1383-1389 (1991)

18. Elfasakhany, A., Mahrous, A.-F.: Performance and emissions assessment of $n$-butanol-methanol-gasoline blends as a fuel in spark-ignition engines. Alex. Eng. J. 55(3), 3015-3024 (2016)

19. Ozsezen, A.N., Canakci, M.: Performance and combustion characteristics of alcohol-gasoline blends at wide-open throttle. Energy 36(5), 2747-2752 (2011)

20. Pourkhesalian, A.M., Shamekhi, A.H., Salimi, F.: Alternative fuel and gasoline in an SI engine: a comparative study of performance and emissions characteristics. Fuel 89(5), 1056-1063 (2010)

21. Ghazikhani, M., Hatami, M., Safari, B., Ganji, D.D.: Experimental investigation of performance improving and emissions reducing in a two stroke SI engine by using ethanol additives. Propuls. Power Res. 2(4), 276-283 (2013)

22. Moxey, B.G., Cairns, A., Zhao, H.: A comparison of butanol and ethanol flame development in an optical spark ignition engine. Fuel 170, 27-38 (2016)

23. Fournier, S., Simon, G., Seers, P.: Evaluation of low concentrations of ethanol, butanol, BE, and ABE blended with gasoline in a direct-injection, spark-ignition engine. Fuel 181, 396-407 (2016)

24. Turner, J., Pearson, R., Dekker, E., Iosefa, B., Johansson, K., Ac Bergström, K.: Extending the role of alcohols as transport fuels using iso-stoichiometric ternary blends of gasoline, ethanol and methanol. Appl. Energy 102, 72-86 (2013)

25. Canakci, M., Ozsezen, A.N., Alptekin, E., Eyidogan, M.: Impact of alcohol-gasoline fuel blends on the exhaust emission of an SI engine. Renew. Energy 52, 111-117 (2013)

26. Chen, R.-H., Chiang, L.-B., Wu, M.-H., Lin, T.-H.: Gasoline displacement and NOx reduction in an SI engine by aqueous alcohol injection. Fuel 89(3), 604-610 (2010)

27. Gu, X., Huang, Z., Wu, S., Li, Q.: Laminar burning velocities and flame instabilities of butanol isomers-air mixtures. Combust. Flame 157(12), 2318-2325 (2010)

28. Srinivasan, C.A., Saravanan, C.: Study of combustion characteristics of an SI engine fuelled with ethanol and oxygenated fuel additives. J. Sustain. Energy Environ. 1(2), 85-91 (2010)

29. He, B.-Q., Liu, M.-B., Yuan, J., Zhao, H.: Combustion and emission characteristics of a HCCI engine fuelled with $n$-butanolgasoline blends. Fuel 108, 668-674 (2013)

30. Merola, S.S., Tornatore, C., Marchitto, L., Valentino, G., Corcione, F.E.: Experimental investigations of butanol-gasoline blends effects on the combustion process in a SI engine. Int. J. Energy Environ. Eng. 3(1), 6 (2012)

31. Elfasakhany, A.: Experimental investigation on SI engine using gasoline and a hybrid iso-butanol/gasoline fuel. Energy Convers. Manage. 95, 398-405 (2015)
32. Feng, R., Yang, J., Zhang, D., Deng, B., Fu, J., Liu, J., Liu, X.: Experimental study on SI engine fuelled with butanol-gasoline blend and $\mathrm{H} 2 \mathrm{O}$ addition. Energy Convers. Manage. 74, 192-200 (2013)

33. Singh, S.B., Dhar, A., Agarwal, A.K.: Technical feasibility study of butanol-gasoline blends for powering medium-duty transportation spark ignition engine. Renew. Energy 76, 706-716 (2015)

34. Galloni, E., Fontana, G., Staccone, S., Scala, F.: Performance analyses of a spark-ignition engine firing with gasoline-butanol blends at partial load operation. Energy Convers. Manage. 110, 319-326 (2016)

35. Yang, J., Wang, Y., and Feng, R. The performance analysis of an engine fueled with butanol-gasoline blend. SAE Technical Paper, 2011

36. Heywood, J. B.: Internal combustion engine fundamentals. McGraw Hill, Singapore (1988)

37. Bata, R.M., Elrod, A.C., Rice, R.W.: Emissions from IC engines fueled with alcohol-gasoline blends: a literature review. J. Eng. Gas Turbines Power 111(3), 424-431 (1989)

38. Wallner, T., Miers, S.A., McConnell, S.: A comparison of ethanol and butanol as oxygenates using a direct-injection, spark-ignition engine. J. Eng. Gas Turbines Power 131(3), 032802 (2009)

39. Lapuerta, M., Garcia-Contreras, R., Campos-Fernández, J., Dorado, M.P.: Stability, lubricity, viscosity, and cold-flow properties of alcohol-diesel blends. Energy Fuels 24(8), 4497-4502 (2010)

40. Jin, C., Yao, M., Liu, H., Chia-fon, F.L., Ji, J.: Progress in the production and application of $n$-butanol as a biofuel. Renew. Sustain. Energy Rev. 15(8), 4080-4106 (2011)

41. Deng, B., Yang, J., Zhang, D., Feng, R., Fu, J., Liu, J., Li, K., Liu, X.: The challenges and strategies of butanol application in conventional engines: the sensitivity study of ignition and valve timing. Appl. Energy 108, 248-260 (2013)

42. Mittal, N., Athony, R.L., Bansal, R., Kumar, C.R.: Study of performance and emission characteristics of a partially coated LHR SI engine blended with n-butanol and gasoline. Alex. Eng. J. 52(3), 285-293 (2013)

43. Broustail, G., Halter, F., Seers, P., Moréac, G., Mounaim-Rousselle, C.: Comparison of regulated and non-regulated pollutants with iso-octane/butanol and iso-octane/ethanol blends in a portfuel injection spark-ignition engine. Fuel 94, 251-261 (2012)

Publisher's Note Springer Nature remains neutral with regard to jurisdictional claims in published maps and institutional affiliations. 